\title{
Discovery Learning Development to Improve Learning Result of Location Analysis for Students of Geography Department
}

\author{
${ }^{1}$ Hilda Vemy Oroh* \\ Geography Department \\ Universitas Negeri \\ Manado \\ Tondano, Indonesia \\ vemyoroh@unima.ac.id \\ Recky H. E. Sendouw \\ Public Administration Science Study \\ Program \\ Faculty of Social Sciences \\ Universitas Negeri Manado \\ Tondano, Indonesia \\ reckysendouw@unima.ac.id
}

\author{
${ }^{2}$ Hermon Maurits Karwur \\ Social Study Education Department \\ Universitas Negeri Manado \\ Tondano, Indonesia \\ hermonkarwur@unima.ac.id
}

\author{
${ }^{3}$ Xaverius Erick Lobja \\ Geography Education Department: \\ Universitas Negeri Manado \\ Tondano, Indonesia \\ ericklobja@unima.ac.id
}

\begin{abstract}
The main problem of research in the learning process of location analysis due to the instructor has not applied discovery learning methods. This Research aimed to improve the quality of the learning process and to improve learning outcomes in socio-economic geography courses in Universitas Negeri Manado, Geography education study program students. The research method is descriptive, by nature developmental. Research conducted on a geography education study program that taken a location analysis course with a total of 25 students as purposive sampling. The results showed discovery learning methods are very effective to improve learning outcomes in the Location Analysis course of geography education study program at the Faculty of Social Science of Universitas Negeri Manado (UNIMA). The results show throughout students participating in the learning program obtaining $\geq 70$ declared as passing grade score.
\end{abstract}

Keywords: Learning, Discovery, Geography

\section{INTRODUCTION}

In teaching and learning processes that are implemented at all levels of education nowadays, not be released from various problems of learning. It is generally stated Indonesia still faces problems related to the quality of education, i.e. currently the quality of education in Indonesia is stated low. This is certainly directly related to the quality of human resources in general. The investment of moral value to form good character in human being's life can be accomplished through formal education and each subject has role in the process of investing value to form a good character. In addition, the other activities are also opened for the process of investing value. Therefore, the forming and investing life values process in learning activity demand example [1]. These problems have been conducted variously treatment to solve them, but it is not finished. This means the problem of quality education is a big problem for Indonesia [2] Geography learning is geography that is taught at the primary and secondary school levels. The object of geographic study is none other than the geosphere, namely the surface of the earth which consists of the atmosphere (air layer), lithosphere (rock layer / earth crust), hydrosphere (water layer), and biosphere (life layer). Geography is one of the eyes lessons in SMA (Middle School Above) separately; while in junior high school (Middle School) as part of the social studies subject (Science Social knowledge). Study in the eye Geography lessons are meant to be humans, both as individuals and as a nation, can understand about environment of the state and nation of Indonesia and other nations of the world [3]. Geography is a science to support life throughout life and promote life improvement. Geography learning process is necessary associate with skills and habituation, in addition to understanding concepts. References [3], [4] stated that learning soft skills is responsible responsibility and discipline integrated through the practice of patiseri has been able to improve and maintain responsible behavior and discipline; as well as learning soft skills. This integrated system is proven to be effective at improving mastery of responsibility and discipline. Learning is done through a process habituation, followed by selfexpression; and integrated soft skills learning will be more effective, when the role of the lecturer also effective in giving feedback and motivate on an ongoing basis during learning [3], [4]. 
According to the problems stated, various efforts have been made action as an alternative to solve the problem, to improve the quality of education at all levels. The efforts have been made include develop learning tools and improve teaching planning, improvement of administrative systems of education and improvement of the learning process. All things are done to make improvements in the administration of education to create a process of quality learning. One cause the low quality of education is the factor of the teaching staff which is not fully stated professional in conducting their duties and responsibilities the answer is as an educational staff.

Related to the description is the demands and needs for the teaching of geography nowadays, There should the teaching staff have a set of professional knowledge and abilities that can be seeded, to conduct the task and his responsibilities as a teacher in the process of effective learning and influence positive for students. Professionalism ability the teacher determines the success of the process learning. he problem is still faced in the process of learning geography, include among other things stated that learning now gives a lot of disappointment, due to the level of knowledge, understanding of teaching material is relatively low.

According to Sumarmi [5] factor the causes are: (a) there are still many students including students who have not been able to understand geographic concepts, those related to location analysis, (b) most students have still encountered a problem when linking between learned course with the conditions real in contextual environments [6]. Observation results as part of the study preliminary have been done, then can be explained the problems faced by education providers in this case study programs Geography Education, especially in implementation learning Location Analysis courses, as follows:

1. Learning planning has been done but not in detail and integrated of all components learning,

2. The learning process is dominated by cognitive or theoretical based learning with the dominant way of presenting lectures.

3. The contextual learning environment is needed, which allows students to make observations to the real environment

4. Developed learning-oriented learning activities and concepts related to the principal discussion by conducting studies in an open environment.

As a result, student learning outcomes in geography studies social economy tends to below. According to the problems, then researchers develop a concept of thinking is to develop deep discovery learning methods learning process of location analysis course in Geography Education students. Discovery learning is seen as a method that develops students' abilities and skills in conducting studies or environmental observations according to the subject matter. The development of appropriate learning methods in the learning process is seen as the need to build a learning process effective, fun, innovative and productive use encourages students to optimize their potential and ability to learn. Due to the existing development of innovative learning methods expected as a positive effort to improve the application of geography teaching methodologies, more specifically on learning socio-economic geography.

By making efforts to improve the methodology of Geography teaching is a part of the business achieve in the learning process and the successful implementation of the learning process of geography that is expected to have an impact on general learning. In general, it can be explained the success of the learning process is even the administration of education, is very much determined by various devices, such as a) hardware which consists of classrooms as a space for learning activities, tools that support practical activities, laboratories and libraries and workshop; b) software consisting of: packages curriculum, learning program planning, management school and study program, instructional system learning; 3) brainwave consists of: component of teachers or teaching staff, school principals, children students and people related to the process education [5].

Based on the explanation, teachers or lecturers as teaching in universities has an important role in the success of the learning process and the success of the participant's students include activities conducting the study. Due to teacher is the manager learning activities, for the successful implementation learning is very much determined by the instructor.

Based on the identification of the results of the research problems as follows:

1. The lesson plan has been done but not in detail and integrated of all components of learning,

2. The learning process is dominated by based learning cognitive or theoretical which dominant presentation of lectures.

3. The learning activity is not oriented in a contextual environment, which gives a chance to students to make observations to a real environment, 
4. Learning is not developed as an oriented activity to find out the problems by him/herself and concepts related to the subject by conducting studies in an open environment. As a result, student learning outcomes in social geography studies tend to below.

\section{RESEARCH METHODS}

The method used in this study is a developmental description, which aims to develop learning methods, in case discovery development methods in learning Socioeconomic geography. Research subjects are students of geography education study program which taken socioeconomic geography course. They are 45 students from the Geography Education Department.

\section{RESULT AND DISCUSSION}

\section{Observation Activities 1:}

Observation activities or agricultural activity. After students have done learning activities, by making observations, then the following results are obtained; The results showed students who scored $>70$ areas 40 students or $88.9 \%$, and students who get an achievement score $\leq$ of 5 students or $11.1 \%$. Based on the results, it can be explained most participants of the learning activities program in the course of Analysis Location, for the first observation activity obtained performance scores as the Success category, while only a small percentage of those who scored lower than the target.

\section{Observation Activity 2:}

Observation activities or industrial activity. The results show students who score $>70$ are 42 students or $93.3 \%$, and students who get a low score are 3 students or $6.7 \%$. Based on the results, it can be explained most participants of the learning program in the course Location Analysis, for the first observation activity, the achievement score categorized as successful while only some of the score was not successful. According to the data aforesaid and success standards, provides instructions that learning the discovery method has been encouraging students in conducting learning activities. Students turned out to have good motivation to conduct learning activities through field activities observations for students to get good learning outcomes. This means the learning method is effective to improve student learning outcomes in teaching Location Analysis.
Developed by J.S. Bruner, the discovery learning strategy is a motivating learning strategy actualized based on students' own activities and observations. Unlike the demonstration method; the discovery learning strategy arranges a learning environment based on students' efforts instead of presenting the information to students. Bruner states that students are required to think like scientists; and instead of presenting the concepts and principles, they must be directed to make research and experiments, find out concepts and develop analysis and synthesis abilities [6].

Learning activities are carried out in an interactive, inspirational, fun, challenging, motivating learners to participate actively, and provide space sufficient for initiative, creativity, and independence according to talents, interests, and physical and psychological development learners.

\section{CONCLUSION}

Based on the results of the analysis and discussion of the study, there are some conclusions can be made as follows:

1. The application of the discovery method turned to be very effective to improve students' learning outcomes on the Location Analysis course Faculty of Social Science Geography Education Study Program of UNIMA.

2. The Discovery method is developed learning-based through the contextual environment.

\section{ACKNOWLEDGMENT}

Thank you for Dean Faculty of Social Sciences for supporting this research.

\section{REFERENCES}

[1] G. D. Sumilat, T. D. Wua, A. L. Lonto, J. Robot, and S. A. S. L. Tombeg, 'The Role of Teacher and Technological Advancement in The Process of Forming Moral Value and Character', in $1 s t$ International Conference on Social Sciences (ICSS 2018), 2018

[2] E. Mulyasa, 'Menjadi guru profesional menciptakan pembelajaran kreatif dan menyenangkan', Bandung: Remaja Rosdakarya, pp. 24-29, 2005.

[3] D. Sugandi, 'Pembelajaran Geografi sebagai Salah Satu Dasar Pembentukan Karakter Bangsa', Sosio Humanika, vol. 8, no. November, pp. 241-252, 2015. 
[4] S. Hamidah and S. Palupi, 'Peningkatan Soft Skills Tanggung Jawab dan Disiplin Terintegrasi Melalui Pembelajaran Praktik Patiseri', J. Pendidik. Karakter, no. $2,2012$.

[5] Sumarmi, Model-model Pembelajaran Geografi.

\section{Malang: Aditya Media Publishing, 2012.}

[6] A. Ilhan and A. E. Gülersoy, 'Discovery Learning Strategy in Geographical Education: A Sample of Lesson Design.', Rev. Int. Geogr. Educ. Online, vol. 9, no. 3, pp. 523-541, 2019. 